\title{
Plasma CCL16 Chemokine Secretion and Expression in Liver Tissue of Patients with Autoimmune Hepatitis: A Pilot Study
}

\author{
Adriana Fabiola Romano-Munive ${ }^{1}$ (D) Carlos Moctezuma-Velázquez ${ }^{2}$ (D) Daniel Keil-Ríos ${ }^{2}$ \\ Sara Sixtos-Alonso² (D) Rodolfo Isidro Que-Rodríguez ${ }^{2}$ (D) • David Kershenobich-Stalnikowitz ${ }^{2}$ \\ ${ }^{1}$ Doctor of Medical Science candidate (DMSc) in medical, odontological and health sciences, Faculty of Medicine, National Autonomous \\ University of Mexico (UNAM), Mexico City, Mexico. \\ ${ }^{2}$ Gastroenterology Department, National Institute of Medical Sciences and Nutrition Salvador Zubiran. Mexico City, Mexico.
}

Acta Gastroenterol Latinoam 2021;51(3):321-326

Received: 12/01/2021 / Accepted: 04/09/2021 / Published online: 27/09/2021 / https://doi.org/10.52787/mmne5431

\section{Summary}

Introduction and aims. CCL16 is a recently discovered chemokine, mainly synthesized in the liver. Its expression in autoimmune hepatitis is still unknown. The main objective of this investigation is to determine the levels of CCL16 in plasma and liver tissue of patients diagnosed with autoimmune hepatitis. Materials and methods. Patients with clinical and serologic findings consistent with probable autoimmune hepatitis, who underwent a percutaneous liver biopsy, were included. Tissue expression of CCL16 messenger RNA was assessed with real-time polymerase chain reaction. Plasma CCL16 levels were determined by enzyme-linked immunosorbent assay. Controls had normal liver function tests and a Fibroscan-502 ${ }^{\circledR}$ with no signs of fibrosis or steatosis. Results. Liver biopsy was performed in 14 patients: in 10 cases was confirmed the diagnosis of autoimmune hepatitis and in 4 cases the biopsy was compatible with steatosis/

Correspondence: Adriana F Romano-Munive

Médica Sur, Puente de Piedra 150, Tlalpan (ZP 14050). Mexico City,

Mexico. / Tel.: +5215520826588

Email:fab_romanom@hotmail.com steatohepatitis. Twenty-two patients were included in the control group. No statistically significant differences were found between the groups in terms of plasma CCL16 levels $(p=N S)$. Its concentration was not associated with the presence of liver fibrosis in the biopsy $(p=0.28)$ or with the response after 6 months of treatment $(p=0.90)$. Conclusion. This is a study that has determined the expression of chemokine CCL16 in patients with autoimmune hepatitis. It was observed that the plasma secretion of CCL16 decreased in the autoimmune hepatitis group, compared to the control group, but this difference was not statistically significant.

Keywords. CCL16 protein, human, CC chemokines, hepatitis autoinmune, fatty liver.

\section{Secreción de quimioquina CCL16 en plasma y expresión en el tejido hepático en pacientes con hepatitis autoinmune: un estudio piloto}

\section{Resumen}

Introducción y objetivos. CCL16 es una quimioquina de reciente descubrimiento, que se sintetiza principalmente en el higado. Aún se desconoce su expresión en la hepatitis autoinmune. El principal objetivo de esta investigación es determinar la secreción plasmática de CCL16 y su expresión 
en tejido hepático de pacientes diagnosticados con hepatitis autoinmune. Materiales y métodos. Se incluyeron pacientes con hallazgos clínicos y serológicos consistentes con una probable hepatitis autoinmune, a los que se les realizó una biopsia hepática percutánea. La expresión del ARN mensajero de CCL16 en tejido fue determinada por reacción en cadena de la polimerasa en tiempo real. Los niveles plasmáticos de CCL16 se determinaron mediante un ensayo por inmunoabsorción ligado a enzimas. Los controles presentaron pruebas de función hepática normales y un Fibroscan-502 ${ }^{\circledR}$ sin fibrosis ni esteatosis. Resultados. Se realizó la biopsia hepática en 14 pacientes, en 10 casos se confirmó el diagnóstico de hepatitis autoinmune y en 4 casos la biopsia fue compatible con esteatosis/esteatohepatitis. En el grupo control fueron incluidos 22 pacientes. No se encontraron diferencias significativas entre ambos grupos en relación a la secreción plasmática de CCL16 ( $p=N S)$. Ésta no se asoció con la presencia de fibrosis en la biopsia hepática $(p=0,28) n i$ con la respuesta al tratamiento a los 6 meses de seguimiento $(p=0,90)$. Conclusión. Este es un estudio que ha determinado la expresión de CCL16 en pacientes con hepatitis autoinmune. Se observó que la secreción plasmática de CCL16 estaba disminuida en el grupo con HAI en comparación con el grupo control, sin embargo la diferencia no fue estadisticamente significativa.

Palabras clave. Proteina CCL16, humano, quimioquina CC, hepatitis autoinmune, higado graso.

\section{Abbreviations}

AIH: Autoimmune hepatitis.

IBS: Irritable bowel syndrome.

$U C$ : Ulcerative colitis.

IAIHG: The International Autoimmune Hepatitis Group. ANA: Antinuclear antibodies.

ASMA: Anti-smooth muscle antibodies.

ALKM-1: Anti-liver-kidney microsomal type 1 antibodies.

LSM: Liver stiffness measurement.

CAP: Controlled attenuation parameter.

$m R N A$ : Messenger RNA.

RT-PCR: Real Time polymerase chain reaction.

cDNA: Complementary strand of DNA.

G6PD: Glucose 6 phosphate dehydrogenase.

ELISA: Enzyme-linked immunosorbent assay.

TE: Transient elastography.

$I Q R / M$ : Interquartile range/median.

ALT: Alanine aminotransferase.

AST: Aspartate aminotransferase.

ALP: Alkaline phosphatase.

CONACYT: Consejo Nacional de Ciencia y Tecnología

(National Council of Science and Technology).

\section{Introduction}

CCL16 is a recently discovered chemokine, which is mainly produced in the liver. CCL16 is found in the plasma but not in the serum of healthy adults. ${ }^{1}$ It has been evaluated in some inflammatory diseases, such as preeclampsia, endometriosis, eosinophilic pneumonia, irritable bowel syndrome (IBS) and ulcerative colitis (UC). However, its expression in autoimmune hepatitis (AIH) is unknown.

In the pathophysiology of $\mathrm{AIH}$, it is observed that in a genetically predisposed individual exposed to an environmental factor that triggers the formation of antigens, these, when recognized by $T$ lymphocytes, cause their activation. CD4 lymphocytes promote the differentiation of cytotoxic T lymphocytes, Th17 cells and the differentiation of B cells into plasma cells. In addition, there are deficiencies in the number and function of regulatory $\mathrm{T}$ lymphocytes, which favors the loss of selftolerance and allows chronic inflammation in liver tissue. Since CCL16 chemokine works on the receptors of the involved cells, promotes the activation of $\mathrm{T}$ lymphocytes and monocytes, and stimulates the differentiation of $\mathrm{T}$ lymphocytes into cytotoxic $\mathrm{T}$ lymphocytes, it could have a role in this disease. ${ }^{2-4}$

The aim of this study was to determine CCL16 levels in plasma and liver tissue of patients diagnosed with AIH, to assess whether CCL16 plasma levels are associated with the presence of fibrosis on liver biopsy or response to treatment, and to compare CCL16 plasma levels between patients with $\mathrm{AIH}$ and controls.

\section{Material and methods}

This is a pilot, case-control study, which was approved by our institutional review board. It included patients in whom clinical and serologic findings were consistent with probable AIH, according to the revised International Autoimmune Hepatitis Group (IAIHG) score, and underwent percutaneous liver biopsy from March 2013 to August 2014 at the National Institute of Medical Sciences and Nutrition Salvador Zubirán. ${ }^{5,6} \mathrm{~Pa}-$ tients were tested for viral hepatitis, immunoglobulin $\mathrm{G}$, antinuclear antibodies (ANA), anti-smooth muscle antibodies (ASMA) and anti-liver-kidney microsomal type 1 antibodies (ALKM-1). A serum titer of 1:80 or higher was considered positive for ANA and ASMA, and a titer of 1:40 or higher was considered positive for ALKM-1.

We excluded patients who had received treatment prior to liver biopsy, had history of hepatotoxic drugs intake, chronic hepatocellular damage on ultrasound, contraindications for liver biopsy (platelets $<50,000$, INR $>1.4$, 
suspected hemangioma or vascular tumor, morbid obesity or hemophilia). In all patients, a percutaneous liver biopsy with ultrasound marking was performed, a part of the liver tissue was fixed with paraformaldehyde and paraffin sections were obtained; an experienced gastropathologist confirmed or ruled out the HAI diagnosis and evaluated the degree of portal inflammation and fibrosis. Another section of the tissue was preserved in RNAlater solution (Ambion Life Technology, USA) at $-70^{\circ} \mathrm{C}$ until CCL16 expression was analyzed.

For the control group, we included subjects over 18 years of age without alcohol or hepatotoxic drug intake, no obesity or overweight, with normal liver function tests and a Fibroscan-502 ${ }^{\circledR}$ (Echosens, Paris) showing no fibrosis or steatosis [i.e. liver stiffness measurement $(\mathrm{LSM})<5.5 \mathrm{kPa}$ and controlled attenuation parameter $(\mathrm{CAP})<233 \mathrm{~dB} / \mathrm{m}])$. Controls were selected from medical staff or healthy relatives of the cases.

\section{Measure of CCL16 expression}

The messenger RNA (mRNA) level of CCL16 was measured by real-time polymerase chain reaction (RTPCR). Total RNA was obtained from each liver biopsy. The liver tissue was crushed and homogenized with electric polytron (Kinematica AG, PT-1300D Dispersing and Mixing Technology, Bohemia, NY) in guanidine HCL and sodium phosphate solution according to the manufacturer's instructions of the High Pure RNA Tissue Kit (Roche Diagnostics GmbH, Germany). Quantity and purity of total RNA obtained was assessed by spectrophotometry in Epoch 2.0 (Biotek Instruments, Inc. USA).

The complementary DNA (cDNA) strand was synthesized by reverse transcription with $2.5 \mu \mathrm{g}$ of total RNA according to the instructions in the Transcriptor First Strand cDNA Synthesis Kit (Roche Diagnostics GmbH, Germany) on a Light Cycler 2.0. Thermalcycler Instruments (Roche Diagnostics GmbH, Germany).

The expression of CCL16 mRNA in cDNA was assessed by RT-PCR. The primers sequence for the CCL16 gene was designed with the online program Probe Finder http://www. universalprobelibrary.com. The sequences were CCL16 right primer: -5' ggT gTT CAC CCA CTC Agg A-3'; CCL16 left primer: -5' CTg CCC TgT CTC TCC TTg TC-3' with TaqMan probe No 71 from Universal ProbeLibrary Set, Human (Roche Diagnostics GmbH, Germany). The reaction mixture contained $200 \mathrm{nM}$ of each primer, $100 \mathrm{nM}$ of TaqMan probe, $0.5 \mathrm{U}$ uracil glycosylase, and $2 \mu \mathrm{l}$ of cDNA according to Light Cycler TaqMan Master reaction mix IX (Roche Diagnostics GmbH, Germany). According to the amplification protocol, 45 cycles of am- plification were performed, each including: denaturation at $95^{\circ} \mathrm{C}$ for 10 seconds, annealing at $60^{\circ} \mathrm{C}$ for 10 seconds and extension at $72^{\circ} \mathrm{C}$ for 1 second. The protocol was finished with a cooling cycle at $40^{\circ} \mathrm{C}$ for 30 seconds, on Light Cycler 2.0 Instruments (Roche Diagnostics GmbH, Germany).

A relative quantification of CCL16 was determined by the software once the amplification was performed using the simultaneous expression of the reference gene. Glucose 6 phosphate dehydrogenase (G6PD), the sequences specific primers for the G6PD gene were: G6PD right $-\mathrm{gC}$ ATT TCA ACA CCT TgA CC -3', G6PD left -5'-CTg CAg ATg CTg TgT CTg gT-3' and TaqMan probe No 22 of Universal Probe-Library Set, Human (Roche Diagnostics GmbH, Germany)

\section{CCL16 in plasma}

On the day of liver biopsy, a peripheral blood sample was taken from each participant and centrifuged to obtain plasma (clinical centrifuge, Thermo Scientific ST 26 Sorvall). CCL16 level was measured in plasma according to CCL16 enzyme-linked immunosorbent assay (ELISA) (Human) kit, (Abnova, USA), with a lower limit of detection of $8 \mathrm{pg} / \mathrm{ml}$, reading of the colorimetric reaction was performed on the Epoch2TC microplate reader (BioTek Instruments Inc., USA).

\section{Transient elastography (TE)}

LSM was performed with TE through the FibroScan $502^{\circledR}$ device (Echosens, Paris, France). All examinations were made with the $\mathrm{M}$ probe according to the skin-capsule distance, as recommended. Patients had to be fasting for at least 4 hours before the study. A study was considered technically unreliable if it had fewer than 10 valid measurements, a success rate $<60 \%$, and/or an $\mathrm{IQR} / \mathrm{M}$ (interquartile range/median) $>30 \%$. All studies were performed by the same operator, who had performed more than 500 LSMs. In addition to LSM, this device also measures CAP.

Fibroscan was performed as previously described. Briefly, with the patient lying in dorsal decubitus, the right arm in maximum abduction, the probe tip was covered with coupling gel and placed perpendicular to the skin between the rib bones, at the intersection between the mid-axillary line and a line drawn at the level of the xyphoid process. The operator, assisted by ultrasound motion time images, located a portion of the liver free of large vascular structures and obtained the acquisitions. ${ }^{7}$

\section{Statistical methods}

Using the formula for two means of two independent groups it was estimated that 32 patients (16 in each arm) would be needed to detect a difference of $5 \mathrm{ng} / \mathrm{mL}$, with 
a power of $80 \%$ and a two-tailed alpha of $5 \%$. Numerical variables were presented as mean and standard deviation or median and IQR, and categorical variables as absolute and relative frequencies, excluding observations from the denominator when missing. The Mann-Whitney U test was used to compare medians between groups. The association between a categorical variable (degree of fibrosis on liver biopsy or 6-month response to treatment) and a continuous variable (plasma CCL16 level) was resolved with logistic regression analysis, with a $\mathrm{P}$ value of $\leq 0.05$ considered statistically significant. Data analysis was performed with Stata 14 (College Station, TX, USA).

\section{Results}

Liver biopsy was performed in 14 patients, of which 10 confirmed AIH, while in 4 the biopsy was compatible with steatosis/steatohepatitis. Twenty-two patients were included in the control group, $81.8 \%(18 / 22)$ were women and the mean age was 29 (IQR, 27-31) years. There were differences in sex, age, proportion of fibrosis, alanine aminotransferase (ALT), aspartate aminotransferase (AST) and alkaline phosphatase (ALP) between the control group and the study groups (Table 1).

Table 1. Characteristics of groups

\begin{tabular}{lcc}
\hline Characteristics & $\begin{array}{c}\text { Controls } \\
\mathrm{n}=22\end{array}$ & $\begin{array}{c}\text { AlH } \\
\mathrm{n}=10\end{array}$ \\
\hline $\begin{array}{l}\text { Sex, female, } \mathrm{n}(\%) \\
\begin{array}{l}\text { Age, years } \\
\text { median (IQR) }\end{array}\end{array}$ & $18(81.8)$ & $10(100)^{\star}$ \\
$\begin{array}{l}\text { F0, n (\%) } \\
\text { Total bilirubin, mg/dL } \\
\text { median (IQR) }\end{array}$ & $0.62(0.38-0.82)$ & $42(23-56)^{\star}$ \\
$\begin{array}{l}\text { Direct bilirubin, mg/dL } \\
\text { median (IQR) }\end{array}$ & $0.13(0.1-0.19)$ & $4(40)^{\star}$ \\
$\begin{array}{l}\text { ALT, U/L } \\
\text { median (IQR) }\end{array}$ & $0.24(0.41-2.60)$ \\
$\begin{array}{l}\text { AST, U/L } \\
\text { median (IQR) }\end{array}$ & $6(4-7.75)$ & $57.5(13.5-96)^{\star}$ \\
$\begin{array}{l}\text { ALP, U/L } \\
\text { median (IQR) }\end{array}$ & $15(12.75-18.5)$ & $44(22.5-86.5)^{\star}$ \\
$\begin{array}{l}\text { Albumin, g/dL } \\
\text { median (IQR) }\end{array}$ & $44.5(38-55.25)$ & $113(74.5-270)^{\star}$ \\
$\begin{array}{l}\text { Globulin, g/dL } \\
\text { median (IQR) }\end{array}$ & $4.5(3.3-4.7)$ & $4.25(3.8-4.5)$ \\
\hline
\end{tabular}

F0: no fibrosis; ALT: alanine aminotransferase; AST: aspartate aminotransferase; ALP: alkaline phosphatase.

${ }^{*} p$-value not significant (NS) control vs HAl.
The secretion of CCL16 in plasma of patients with AIH was 60.25 (IQR, 28.72-289.75) ng/mL and mRNA expression in liver tissue was 14.51 (IQR, 6.08-18.52). Plasma CCL6 secretion in the control group was 77.98 (IQR, 57.05-122.69) ng/mL.

The CCL16 plasma secretion was not associated with the presence of liver fibrosis on biopsy $(p=0.28)$ or with 6 -month response to treatment $(p=0.90)$ in patients with $\mathrm{AIH}$. The expression of mRNA in liver tissue was not associated with the degree of fibrosis, F0-F1 vs F3-F4, $p=0.74$.

No statistically significant differences were found between groups in terms of CCL16 plasma secretion $(p=$ NS). Table 2 .

Table 2. Expression of CCL16 in plasma and liver tissue

\begin{tabular}{lcc}
\hline & $\begin{array}{c}\text { Control group } \\
\mathrm{n}=22\end{array}$ & $\begin{array}{c}\text { AlH group } \\
\mathrm{n}=10\end{array}$ \\
\hline $\begin{array}{l}\text { CCL16 in plasma, } \\
\mathrm{ng} / \mathrm{mL} \text {, median (IQR) }\end{array}$ & $77.98(57.05-122.69)$ & $60.25^{\star}(28.72-289.75)$ \\
$\begin{array}{l}\text { mRNA in liver tissue, } \\
\text { median (IQR) }\end{array}$ & $\mathrm{ND}$ & $14.51(6.08-18.52)$
\end{tabular}

AlH: Autoimmune hepatitis; mRNA: Messenger RNA; ND: Not determined. ${ }^{*} p$-value not significant (NS) control vs HAl.

\section{Discussion}

CCL16 plasma secretion was decreased in the AIH group, compared to controls, but this difference was not statistically significant. Its expression was not associated with the presence of liver fibrosis on biopsy or 6-month response to treatment.

In a study, umbilical cord blood samples were taken of 163 preterm deliveries and 107 immunoproteins were analyzed, $34 \%$ of the patients had preeclampsia and, in these patients, a statistically significant association was found between the disease and the presence of CCL16, CCL24 and CCL23, with CCL16 showing the highest relationship (OR 24.5). This chemokine was also associated with severe intrauterine growth retardation. ${ }^{8}$

In another study, 22 chemokines were measured in the glandular epithelium of healthy women and patients with endometriosis. It was found that CCL16 and CCL22 were elevated in patients with endometriosis, with CCL16 being higher in the ectopic endometrial tissue than in eutopic tissue. This suggested that these two chemokines were involved in the inflammation associated with endometriosis. ${ }^{9}$

In a study conducted in Japan, CCL16 was measured in the bronchoalveolar lavage of 33 patients with eosinophilic pneumonia, 26 patients with sarcoidosis and 10 
healthy patients. It was observed that the values were higher in the first group of patients and that these levels correlated with the number of eosinophils and lymphocytes found in the bronchoalveolar lavage. In patients who presented remission of the disease, a new measurement of CCL16 was performed and it was observed that the values had significantly decreased. These data suggest that this chemokine induces the accumulation of eosinophils and lymphocytes in the lung tissue of patients affected by this pathology. ${ }^{10}$

In IBS, CCL16 has been found to be elevated 7.46fold compared to controls, and 130-fold in IBS patients with constipation vs IBS cases with diarrhea. ${ }^{11}$

In a study conducted in patients with active UC, biopsy macrophages were found to have significant expression of CCL16 compared to inactive patients; therefore, researchers injected tumor cells into mice that produced CCL16, which induced alterations compatible with UC in these animals. ${ }^{12}$

These studies have shown that CCL16 is elevated in several diseases with an inflammatory component in its pathophysiology, which could indicate that this chemokine acts as an anti-inflammatory and/or hepatoprotective factor in these groups of patients.

Our study has several limitations, the most important being the small sample size, and the fact that healthy controls did not have liver biopsy. However, we think that normal liver tests in addition to completely normal LSM-TE and CAP results are a good surrogate of a normal biopsy. Moreover, there was an imbalance in variables such as sex and age between controls and cases.

Nonetheless, our study also has several strengths. First, compared with two previous studies in which plasma concentrations of CCL16 were determined in healthy patients, we included a larger sample size and patients with normal liver function tests and a normal FibroScan. This could be used as a reference when comparing CCL16 levels in other conditions. Second, this is the first study to assess CCL16 levels in liver tissue of patients with AIH.

\section{Conclusion}

In conclusion, plasma secretion of CCL16 was numerically lower in patients with $\mathrm{AIH}$ compared to healthy controls; however, the difference was not significant.Further investigation is required to know if this was due to the small sample size. In addition, the secretion of CCL16 in plasma was not associated with liver fibrosis or 6-month response to treatment.
Conflicts of interest. The authors declare that they have no conflicts of interest.

Funding. Master's scholarship from National Council of Science and Technology (CONACYT). The study sponsors were not involved in the study design, collection, analysis, interpretation of data, writing of the report or the decision to submit this article.

Acknowledgment. To CONACYT (CVU 429684).

Consent for Publication. Written informed consent was obtained from the patient or their parent, guardian, or relative to publish the data andlor clinical images for the benefit of science. A copy of the consent form is available to the editors of this journal.

Intellectual property. The authors declare that the data and tables that appear in this article are original and were made in their belonging institutions.

\section{Copyright}

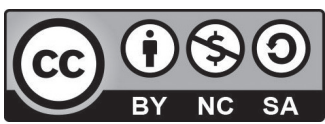

(C) 2021 Acta Gastroenterológica latinoamericana. This is an openaccess article released under the terms of the Creative Commons Attribution (CC BY-NC$S A$ 4.0) license, which allows non-commercial use, distribution, and reproduction, provided the original author and source are acknowledged.

Cite this article as: Romano-Munive AF, Moctezuma-Velázquez C, Keil-Ríos D, et al. Plasma CCL16 Chemokine Secretion and Expression in Liver Tissue of Patients with Autoimmune Hepatitis: A Pilot Study. Acta Gastroenterol Latinoam. 2021;51(3):321-6. https://doi. org/10.52787/mmne 5431

\section{References}

1. Nomiyama H, Hieshima K, Nakayama T, Sakaguchi T, Fujisawa R, et al. Human CC chemokine liver-expressed chemokine/ CCL16 is a functional ligand for CCR1, CCR2 and CCR5, and constitutively expressed by hepatocytes. Int Immunol. 2001;13:1021-9.

2. Cappello P, Caorsi C, Bosticardo M, De Angelis S, Novelli F, et al. CCL16/LEC powerfully triggers effector and antigen-presenting functions of macrophages and enhances $\mathrm{T}$ cell cytotoxicity. J Leukoc Biol. 2004;75:135-42.

3. Kim IS, Jang SW, Sung HJ, Lee JS, Ko J. Differential CCR1-mediated chemotaxis signaling induced by human CC chemokine HCC-4/CCL16 in HOS cells. FEBS Lett. 2005;579:6044-8. 
4. Nakayama T, Kato Y, Hieshima K, Nagakubo D, Kunori Y, et al. Liver-expressed chemokine/CC chemokine ligand 16 attracts eosinophils by interacting with histamine H4 receptor. J Inmmunol. 2004;173:2078-83.

5. Alvarez F, Berg PA, Bianchi FB, et al. International Autoinmmune Hepatitis Group Report: review of criteria for diagnosis of autoimmune hepatitis. J Hepatol. 1999:31(5):929:38.

6. Hennes EM, Zeniya M, Czaja AJ, et al. Simplified criteria for the diagnosis of autoimmune hepatitis. Hepatology 2008;48(1): 169-76.

7. Berzigotti A, Seijo S, Arena U, Abraldes JG, Vizzutti F, Garcia-Pagán JC, et al. Elastography, spleen size, and platelet count identify portal hypertension in patients with compensated cirrhosis. Gastroenterology. 2013;144(1):102-11.

8. Mäkikallio K, Kaukola T, Tuimala J, Kingsmore SF, Hallman M, et al. Umbilical artery chemokine CCL16 is associated with preterm preeclampsia and fetal growth restriction. Cytokine. 2012;60:377-84.
9. Chand AL, Murray AS, Jones RL, Hannan NJ, Salamonsen LA, et al. Laser capture microdissection and CDNA array analysis of endometrium identify CCL16 and CCL21 as epithelial derived inflammatory mediators associated with endometriosis. Reprod Biol Endocrinol. 2007;5:18.

10. Nureki S, Miyasaki E, Usagawa Y, Ueno T, Ando M, et al. Elevated concentrations of liver-expressed chemokine/CC chemokine ligand 16 in broncoalveolar lavage fluid from patients with eosinophilic pneumonia. Int Arch Allergy Immunol. 2009; 150:282-90.

11. Del Valle-Pinero AY, Martino AC, Taylor TJ, Majors BL, Patel NS, et al. Proinflammatory chemokine C-C motif ligand 16 (CCL-16) dysregulation in irritable bowel syndrome (IBS): a pilot study. Neurogastroenterol Motil. 2011;23:1092-7.

12. Pannellini T, Lezzi M, Di Carlo E, Eleuterio E, Coletti A, et al. The expression of LEC/CCL 16, a powerful inflammatory chemokine, is upregulated in ulcerative colitis. Int J Immunopathol Pharmacol. 2004;17:171-80. 